\title{
Seasonal Variation in Live Weight, Testes Size, Testosterone, LH Secretion, Melatonin and Thyroxine in Merino and Corriedale Rams in a Subtropical Climate
}

\author{
By R. Pérez Clariget ${ }^{1,4}$, M. Forsberg ${ }^{2,4}$ and H. Rodriguez-Martinez ${ }^{3,4}$
}

\begin{abstract}
${ }^{1}$ Department of Animal Anatomy and Physiology, Faculty of Agriculture, Montevideo, Uruguay, ${ }^{2}$ Department of Clinical Chemistry and ${ }^{3}$ Department of Obstetrics and Gynaecology, Faculty of Veterinary Medicine, and ${ }^{4}$ Centre for Reproductive Biology, Swedish University of Agricultural Sciences, Uppsala, Sweden.
\end{abstract}

Pérez Clariget R, Forsberg M, Rodriguez-Martinez H: Seasonal variation in live weight, testes size, testosterone, $\mathrm{LH}$ secretion, melatonin and thyroxine in Merino and Corriedale rams in a subtropical climate. Acta vet. scand. 1998, 39, 35-47. - In the present investigation we studied the seasonal changes in live weight and testes and pituitary activity in Merino and Corriedale rams in a subtropical climate. Testes activity was measured as scrotal circumference (SC), plasma concentration of testosterone (T) and release of testosterone after exogenous GnRH injection. LH pulsatility and pituitary LH responsiveness to exogenous $\mathrm{GnRH}$ was measured as an index of pituitary activity. In addition, we wanted to characterize the seasonal pattern of thyroxine $\left(\mathrm{T}_{4}\right)$ secretion and the $24 \mathrm{~h}$ secretory pattern of melatonin (M) at the winter and summer solstices in the 2 breeds. Nine Corriedale and 7 Merino adult (4-6 years) rams were kept on native pasture and managed in one group. Twice a month live weight (LW) and scrotal circumference (SC) were measured. To monitor plasma concentration of testosterone (T), and thyroxine $\left(\mathrm{T}_{4}\right), 5$ animals of each breed were bled every month except during autumn (March-May), when blood samples were collected with 15 day intervals and in spring (October) with 10 day intervals. To monitor pulsatile LH secretion, 3 rams of each breed were bled at $15 \mathrm{~min}$ intervals for $6 \mathrm{~h}$ at the winter and summer solstices and spring and autumn equinoxes. Pituitary $\mathrm{LH}$ and testicular testosterone response to $\mathrm{GnRH}$ injection was performed bimonthly from 2 animals of each breed. No effect of breed was found on any of the variables investigated. An interaction between breed and sampling date was found in LW $(p<0.001)$ and total T response after GnRH challenge $(p<0.001)$. Sampling date had a significant effect $(p<0.001)$ on all the variables studied. In both breeds $\mathrm{SC}$ decreased during autumn and increased during spring with minimum $\mathrm{T}$ concentrations in late autumn and maximum in mid-summer/early autumn. The lowest $(p<0.05)$ number of LH pulses were observed in winter (June) and the highest $(p<0.05)$ in early autumn (March). The highest LH and testosterone response to GnRH challenge was observed in autumn (April) $(p<0.05)$ in both breeds. Baseline concentrations of $M$ were similar in both breeds at the winter and summer solstices and high concentrations were observed during the dark period on both occasions. In both breeds thyroxine was high at the end of winter/spring (February-April) and low from the end of summer to mid-autumn (August-November). The results show that Corriedale and Merino rams under subtropical conditions have annual reproductive cycles. There was an association $(p<0.001)$ between changes in LW and SC in the 2 breeds and this relationship was stronger in Merino rams $\left(R^{2}=0.68\right)$ than in Corriedale $\left(R^{2}=0.33\right)$ which indicates that nutritional factors may have more influence on the reproductive cycle of Merino than Corriedale rams. 


\section{Introduction}

Rams and ewes show marked seasonal variation in breeding activity, which in the ram is associated with variation in testis size (Mickelsen et al. 1981, Islam \& Land 1997) blood concentrations of testosterone (T) (Pelletier et al. 1982, D'Occhio \& Brooks 1983) and pituitary secretion of gonadotrophins (Lincoln \& Short 1980, Pelletier et al. 1982, Pelletier \& Almeida 1987). Lincoln et al. (1990) observed breed differences in the time of maximum testis diameter, testosterone secretion and pituitary activity. In breeds harboured at higher latitudes the seasonal pattern of reproductive activity is governed by changes in photoperiod (for review see: Glover et al. 1990). But also breeds maintained at latidudes where variation in day length is less pronounced respond to changes in photoperiod (Poulton \& Robinson 1987). Genetic factors can influence seasonal reproductive patterns in sheep, since there seems to be breed differences in the interpretation of the photoperiodic signal for the entrainment of the seasonal reproductive cycle (Pelletier et al. 1982, Lincoln et al. 1990). Also other cues may influence breeding activity. Introduction of ewes increases luteinizing hormone (LH) secretion in rams (Sanford et al. 1974) and nutrition in Merino rams can override the effect of photoperiod (Master and Fels 1984, Ritar et al. 1984, Martin et al. 1987, 1990, 1994a,b). The objective of the present work was to study the seasonal changes in live weight (LW) and testes- and pituitary activity in Corriedale and Merino rams in the subtropical climate in Uruguay with moderate variation in day length (latitude $34^{\circ}$ S). Testes activity was measured as scrotal circumference (SC), plasma concentration of $\mathrm{T}$ and release of $\mathrm{T}$ after exogenous gonadotrophin releasing hormone (GnRH) injection. LH pulsatility and pituitary LH responsiveness to exogenous GnRH were measured as an index of pituitary activity. In addition, we wanted to characterize the seasonal pattern of thyroxine $\left(\mathrm{T}_{4}\right)$ secretion and the $24 \mathrm{~h}$ profiles of melatonin (M) at the winter and summer solstices.

\section{Materials and methods}

\section{Animals, location and feeding}

The study was carried out during one year from March to March (autumn to autumn), latitude $34 \mathrm{SL})$. Average temperature during the experiment varied from $10^{\circ} \mathrm{C}$ in July (winter) to $23.3^{\circ} \mathrm{C}$ in December (summer). It rained during all months of the experiment with the minimum in January $(44.9 \mathrm{~mm})$ and the maximum during May (150.4 mm). Day length varies $4 \mathrm{~h}$ $50 \mathrm{~min}$ over the year.

Nine Corriedale and 7 Merino adult (4-6 years) rams were fed on native pasture with spring and summer graminaes as the predominant species. The availability and quality of the forage varied between seasons: $2000-2500 \mathrm{~kg}$ of dry matter per ha with $8 \%$ of protein and $55 \%$ of digestibility during spring. During winter the availability was $1000 \mathrm{~kg}$ of dry matter per ha with $10 \%$ of protein and $60 \%$ of digestibility. All animals were managed in one group and none were used for breeding, but they were all evaluated in a service capacity survey (data to be published elsewhere).

\section{Measurements}

Body weight and SC was recorded twice a month in the morning, except in July and October when 3 measurements were taken. Animals were clinically examined and SC was measured twice with a flexible tape at the widest scrotal diameter by 2 technicians (correlations within and between technicians were: $r=0.99$ and $r=0.98$, respectively) and the average value obtained was used. The scrotum was shorn in order to maintain less than $1 \mathrm{~cm}$ of wool throughout the experiment. Animals were shorn in the end of September (early spring) and their fleece weight registered. LW was estimated through- 
out the experiment in Corriedale rams as described by Gastel et al. (1995). To obtain the LW in Merino rams, the fleece weight was divided by 12 to calculate monthly fleece growth and then subtracted from body weight (Rodriguez 1989).

\section{Blood samples}

Five animals of each breed were randomly selected and bled every month except during March-May (autumn) when blood samples were collected with 15 day intervals and in October (spring) with 10 day intervals to determine T. Three samples were collected from each ram with hourly intervals starting at 9:30 am. The samples from each ram were pooled and used in the $\mathrm{T}$ and $\mathrm{T}_{4}$, assays.

To monitor pulsatile LH secretion, 3 rams of each breed were bled at the winter and summer solstices and spring and autumn equinoxes. Blood samples were collected at 15 min intervals for $6 \mathrm{~h}$ commencing at 9:30 am. The same animals were used to monitor melatonin (M) secretion at the winter and summer solstices. Animals were then bled during $24 \mathrm{~h}$ with $2 \mathrm{~h}$ intervals. Sampling was performed outdoors.

Pituitary LH secretion and testicular T response to $\mathrm{GnRH}$ injection were studied by collecting blood samples bimonthly starting in April (autumn) from 2 animals of each breed. The animals were bled at $20 \mathrm{~min}$ intervals for $4 \mathrm{~h} 20$ min commencing at 9:30 am. Immediately after collection of the second blood sample, each animal received an intravenous injection of 10 $\mu \mathrm{g}$ of GnRH (Fertagyl ${ }^{\circledR}$, Intervet, France).

Blood samples were collected by jugular venipuncture and immediately centrifugated. Blood serum was harvested and stored at $-20^{\circ} \mathrm{C}$ until analyzed.

\section{Hormone assays}

Testosterone and $\mathrm{T}_{4}$ were determined using commercial RIA kits (Coat-A-Count testoste- rone and thyroxine; Diagnostic Products Corporation, Los Angeles, CA, USA) previously validated for sheep plasma (Castrillejo et al. 1995, Pérez et al. 1996). The intra-assay coefficients of variation for $\mathrm{T}$ were $15.4 \%(4.0 \mathrm{nmol}$ $\left.\mathrm{l}^{-1}\right), 5.6 \%\left(22.4 \mathrm{nmol}^{-1}\right)$ and $15.8 \%(48.8 \mathrm{nmol}$ $\left.1^{-1}\right)$ and the corresponding inter-assay coefficients of variation of 5 assays were 14.6, 8\% and $15.4 \%$. The limit of detection (defined as the intercept of maximal binding $-2 \mathrm{SD}$ ) was = $0.2 \mathrm{nmol} \mathrm{1}^{-1}$. The intra-assay and inter-assay coefficients of variation for $\mathrm{T}_{4}$ were $4.5 \%$ and $12 \%$ and the limit of detection was $3.9 \mathrm{nmol} \mathrm{l}^{-1}$. In the $\mathrm{T}$ assay the standard curve and control samples were processed in duplicates and the unknown samples in singletons. In the $\mathrm{T}_{4}$ assay all samples were processed in duplicate.

Plasma content of $\mathrm{LH}$ was determined using a double-antibody radioimmunoassay previously validated for ovine plasma (Forsberg et al. 1993). The intra-assay coefficients of variation were $11.9 \%\left(2.8 \mu \mathrm{g}^{-1}\right)$ and $16.2 \%\left(6.1 \mu \mathrm{g} \mathrm{l}^{-1}\right)$. The corresponding inter-assay coefficients of variation for 6 assays were $8.5 \%\left(2.8 \mu \mathrm{g} \mathrm{l}^{-1}\right)$ and $15.2 \%\left(6.1 \mu \mathrm{g} \mathrm{l}^{-1}\right)$. The limit of detection was $0.4 \mu \mathrm{g}^{-1}$ (maximal binding - $2 \mathrm{SD}$ ). All samples were processed in duplicate.

Melatonin was measured with a commercial ELISA kit (RE54021; IBL, Hamburg, Germany). The samples were treated enzymatically to free $\mathbf{M}$ from its binding proteins. The assay used competition between a biotinylated and a non-biotinylated antigen for a fixed number of antibody binding sites. According to the manufacturer the cross-reactivity of the antibody was $0.5 \%$ for 5 methoxytryptophole, $0.4 \%$ for $\mathrm{N}$-acetyl-serotonin and $0.1 \%$ for 5-methoxytryptamine. Serial dilutions of ovine plasma with high concentrations of $\mathrm{M}$ were parallel to the standard curve. The intra-assay coefficient of variation was less than $10 \%$ for $M$ concentrations between $10-320 \mathrm{pg} / \mathrm{ml}$. The inter-assay coefficient was $8.3 \%(33 \pm 3 \mathrm{pg} / \mathrm{ml})$. The detec- 
tion limit was $5 \mathrm{pg} / \mathrm{ml}$. All samples were processed in duplicate.

\section{Data and statistical analysis}

LH pulses in each individual were calculated using a skewness method (Zarco et al. 1984). For each period the average $\mathrm{LH}$ level $+1 \mathrm{SD}$ was calculated using all the values obtained for each period. After excluding all the $\mathrm{LH}$ values above the mean $+1 \mathrm{SD}$, a new average and SD were calculated. The procedure was repeated until there were no values above the mean +1 SD. LH pulses were defined as at least 2 consecutive peaks (values above the new mean +2 SD). Melatonin baseline concentration in each animal was estimated as the mean of all day values (day was defined as the period from sunrise to sunset). Amounts of T and $\mathrm{LH}$ released during the $240 \mathrm{~min}$ period after $\mathrm{GnRH}$ injection were estimated by calculating the total testosterone and LH response (area under the curve) according to the formula:

$$
\mathrm{R}=\Sigma\left(\left(\mathrm{T}_{\mathrm{i}}+\mathrm{T}_{\mathrm{i}+20}\right) / 2\right) \times 240 \mathrm{~min}
$$

where $\mathrm{i}=0, \ldots . .240 \mathrm{~min}$.

Data were examined by repeated-measures analysis of variance using a split-plot design. The effects of breed, animal within breed, sampling date and breed and sampling date were studied. Individual means were compared by the least significant difference test $(p<0.05)$ when the main effects breed, sampling date and interaction breed and sampling date were significant. Analysis of regression was performed between LW and SC and correlation analysis between SC and T. Results are expressed as mean \pm SE. All analyses were done using SAS 608 (SAS Institute Inc. 1993).

\section{Results}

One Merino ram died in the end of December. Consequently, from January until the end of the trial, data for SC and LW are based on 6 animals and $\mathrm{T}$ and $\mathrm{T}_{4}$ data on 4 animals of the Merino group.

\section{Live weight and scrotal circumference}

Seasonal changes in LW and SC were observed in rams of both breeds during the experimental period (Fig. 1 and Fig. 2). LW was influenced by sampling date $(\mathrm{p}<0.001)$ and there was also an interaction between breed and sampling date $(\mathrm{p}<0.001)$ but there was no overall difference between breeds. Samling date influenced SC $(p<0.001)$ but there was no effect of breed or interaction between breed and sampling date. SC decreased in both breeds by $12 \%$ during autumn (March to June) and remained low during mid-winter. The first significant increase was registered in both breeds in the beginning of early spring (September) and maximum scrotal circumference was reached in mid-spring (November) (20\% increase between June and November). Thereafter SC remained high in both breeds until the end of the trial. There was a significant association between seasonal variation in LW and SC in both breeds $(p=0.0001$; Merino, $\mathrm{R}^{2}=0.68$; Corriedale, $\mathrm{R}^{2}=0.33$ ).

\section{Plasma testosterone}

Variations in plasma concentration of $\mathrm{T}$ during the experimental period are depicted in Fig. 1 and Fig. 2. There was a significant effect of sampling date $(p<0.001)$ but no effect of breed or interaction between breed and sampling date. The minimum $\mathrm{T}$ concentrations were recorded in both breeds in late autumn (May) and maximum concentrations were registered in midsummer and early autumn (January-March). The correlation between SC and concentrations of $\mathrm{T}$ across time was for Merino, $\mathrm{r}=0.49$ and for Corriedale, $r=0.45,(p<0.001)$.

\section{LH pulses}

Due to technical problems during blood sampling in June and September data from one Cor- 


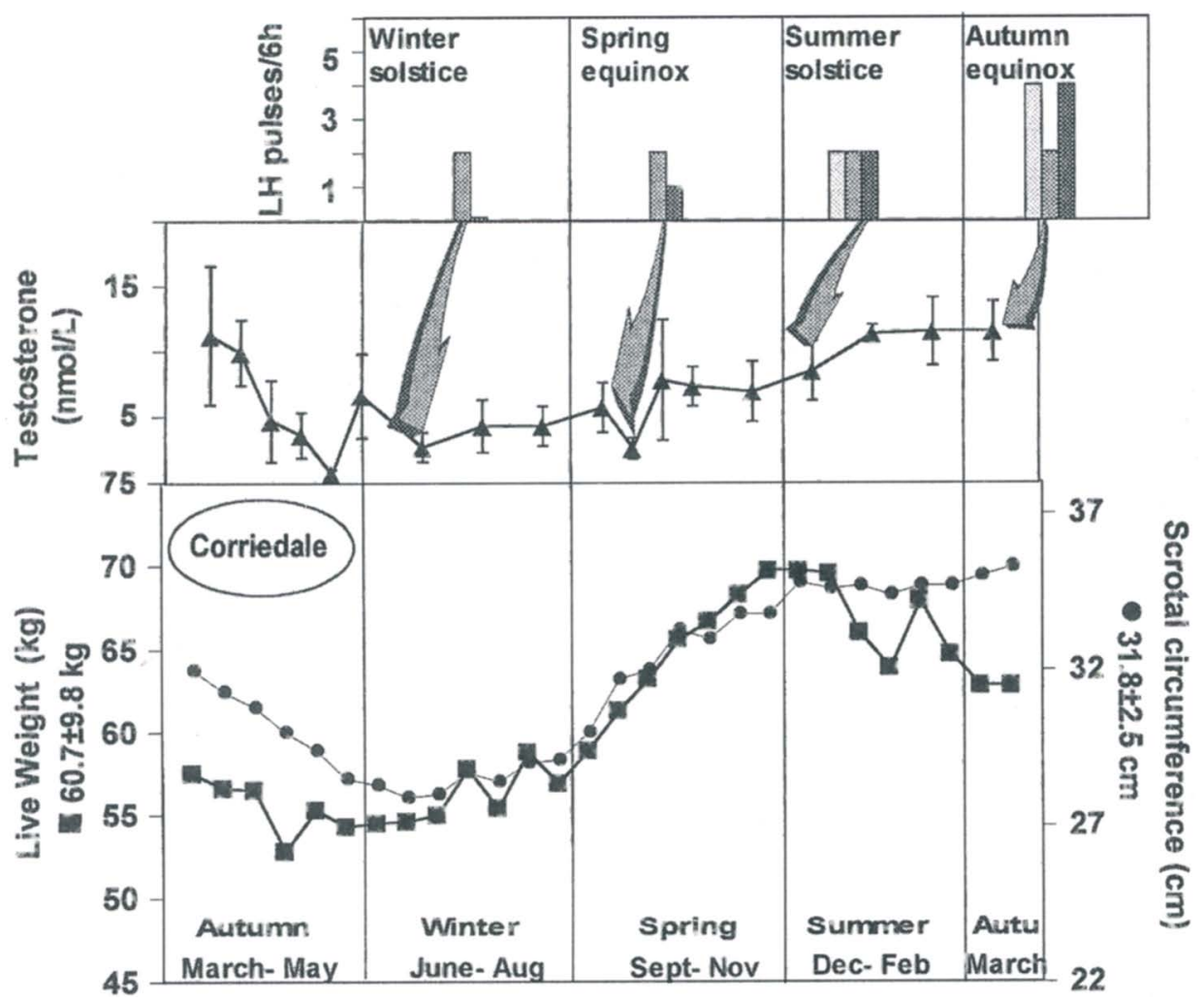

Figure 1. Seasonal patterns of scrotal circumference $(n=9)$, live weight $(n=9)$ and plasma concentration of testosterone (mean \pm s.e.m; $n=5)$ and frequency of LH pulses per $6 h(n=2-3)$ at the winter and summer solstices and autumn and spring equinoxes in Corriedale rams at native pasture in a subtropical climate $\left(34^{\circ} \mathrm{S}\right.$, $56^{\circ} \mathrm{W}$ ). Live weight was corrected for changes in fleece mass. Testosterone data are based on pools of 3 samples collected $60 \mathrm{~min}$ apart.

riedale ram and in June data from one Merino ram were incomplete. The number of $\mathrm{LH}$ pulses per $6 \mathrm{~h}$ from the winter and summer solstices and the spring and autumn equinoxes are shown in Fig. 1 and Fig. 2. There was no difference between breeds or interaction breed and sampling date but there was a significant effect of sampling date $(p<0.001)$ on the number of LH pulses. Regardless of breed, the lowest number of LH pulses were found at the winter solstice in June $(0.75 \pm 0.2$ pulses $/ 6 \mathrm{~h})$ when compared with the other sampling occasions $(p<0.05)$.
Thereafter the frequency increased $(p<0.05)$ to reach similar levels at the spring equinox $(1.8 \pm$ 0.3 pulses $/ 6 \mathrm{~h})$ and summer solstice $(2.3 \pm 0.4$ pulses $/ 6 \mathrm{~h}$ ). The highest $\mathrm{LH}$ pulse frequency $(3.3 \pm 0.3$ pulses $/ 6 \mathrm{~h})$ was registered in both breeds at the autumn equinox in March $(\mathrm{p}<0.05)$.

LH and testosterone release after exogenous GnRH injection

$\mathrm{LH}$ and $\mathrm{T}$ release after injection of $\mathrm{GnRH}$ are illustrated in Fig. 3 and Fig. 4. The total LH re- 


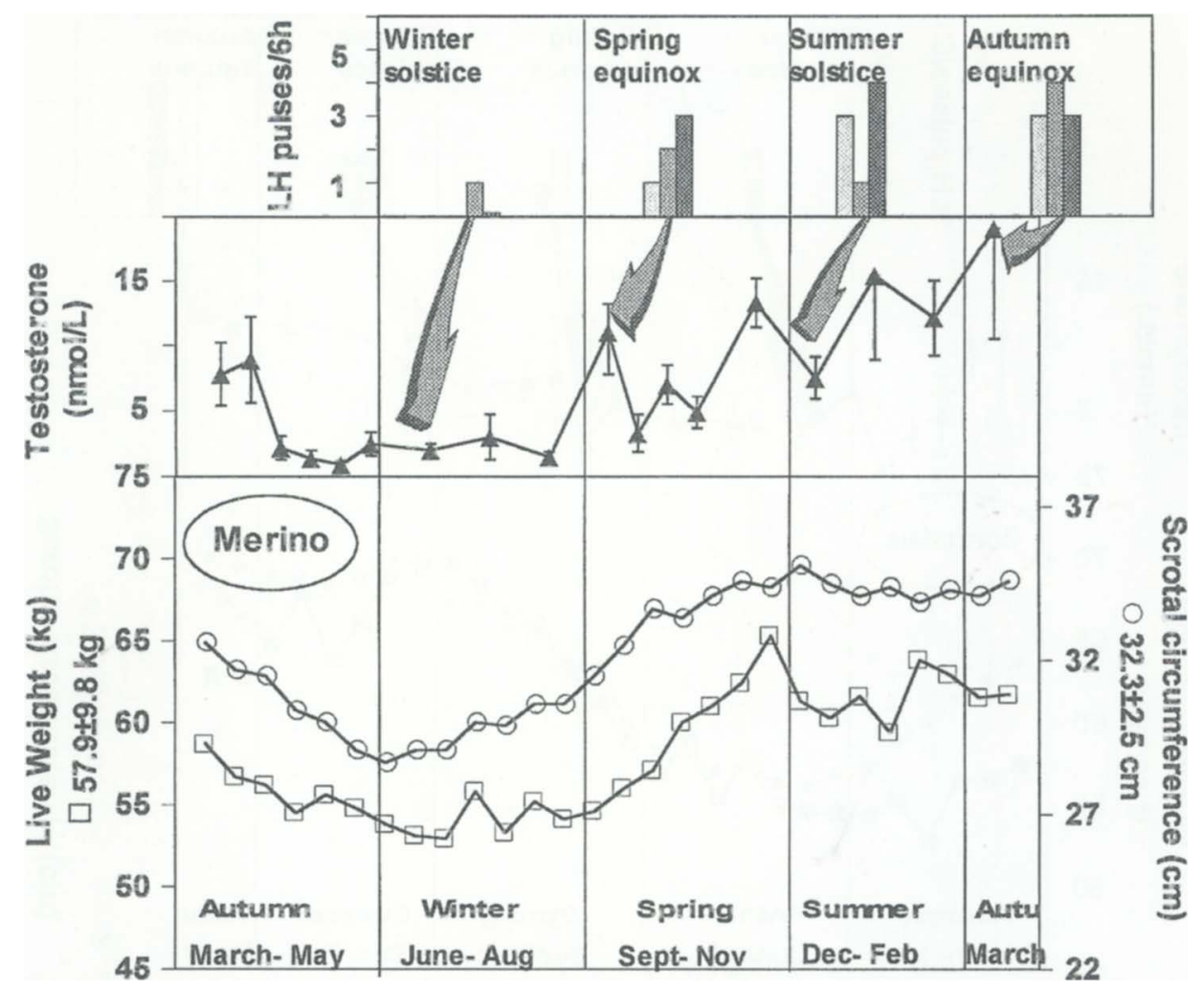

Figure 2. Seasonal patterns of scrotal circumference $(n=6)$, live weight $(n=6)$ and plasma concentration of testosterone (mean \pm s.e.m; $n=4)$ and frequency of LH pulses per $6 h(n=2-3)$ at the winter and summer solstices and autumn and spring equinoxes in Merino rams at native pasture in a subtropical climate $\left(34^{\circ} \mathrm{S}, 56^{\circ} \mathrm{W}\right)$. Live weight was corrected for changes in fleece mass. Testosterone data are based on pools of 3 samples collected 60 min apart.

sponse to GnRH challenge varied by sampling date $(p<0.01)$. There was no overall difference between breeds in $\mathrm{LH}$ response or interaction between breed and sampling date. Regardless of breed, the total $\mathrm{LH}$ response to exogenous $\mathrm{GnRH}$ was highest during autumn (April vs. the other months), decreased in early winter (June vs. April) and increased at the end of winter (August vs. June). In spring (October) the LH response decreased (October vs. August) and increased again in early summer (December vs. October). At the end of summer (February) the total $\mathrm{LH}$ response was intermediate between spring and early summer (February vs. December and October).

The total $\mathrm{T}$ response to $\mathrm{GnRH}$ challenge varied by sampling date $(p<0.001)$ and there was an interaction between breed and sampling date $(\mathrm{p}<0.001)$ but no overall difference between breeds. $T$ response decreased in both breeds from autumn to early winter (April vs. June). The response in Merino rams in autumn was significantly higher than in Corriedale rams. $T$ response increased in both breeds during winter 


\section{Corriedale}

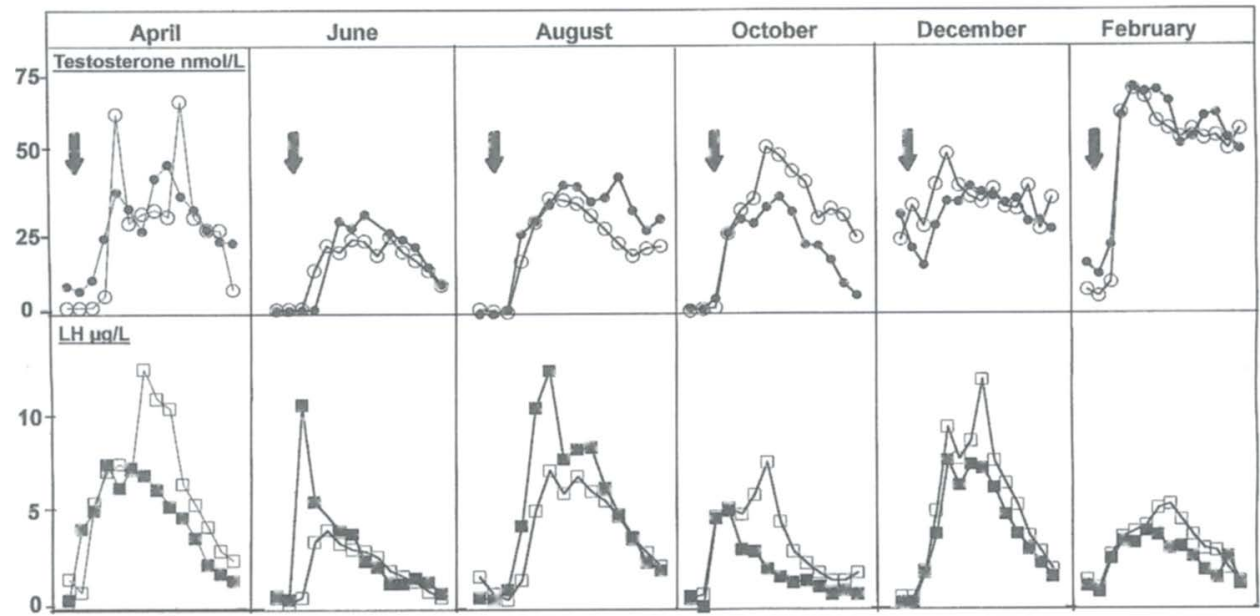

Hormone release 20 minutes before until $\mathbf{2 4 0}$ min after $\mathrm{GnRH}$ injection

Figure 3. Plasma concentrations of LH (lower panel) and testosterone (upper panel) in 2 Corriedale rams after a single intravenous injection of GnRH $(10 \mu \mathrm{g})$ in April, June, August, October, December and February. GnRH was injected immediately after collection of the second blood sample. Animals were grazing on native pasture in a subtropical climate $\left(34^{\circ} \mathrm{S}, 56^{\circ} \mathrm{W}\right)$.

(June vs. August). In spring, Corriedale rams showed a similar response as in late winter (August vs. October), while the response in Merino rams decreased (August vs. October). Both breeds showed an increase from spring to early summer (October vs. December) and early and late summer (December vs. February). Corriedale rams had the highest $T$ response in late summer (February vs. all other months). Merino rams also showed a high response in late summer (February vs. June, August, October and December) but the $T$ response was similar to that found in autumn (April).

\section{Melatonin}

Melatonin profiles of the 2 breeds at the summer and winter solstices are illustrated in Fig. 5. There was a significant effect of sampling date $(p<0.01)$ on $M$ secretion but no effect of breed or interaction breed and sampling date. Baseline concentrations of $\mathrm{M}$ were similar in both breeds at the winter and summer solstices (June: Corriedale; $16.6 \mathrm{pg} \mathrm{ml}^{-1}$, Merino; 16.8 pg ml$l^{-1}$, December: Corriedale; $12.2 \mathrm{pg} \mathrm{ml}^{-1}$, Merino; $11.8 \mathrm{pg} \mathrm{m}^{-1}$ ). High concentrations were observed in both breeds during the dark period at the winter and summer solstice.

\section{Thyroxine}

Thyroxine concentrations varied throughout the experiment in both breeds (Fig. 6) with the highest values at the end of winter and spring (August-November) and the lowest values at the end of summer and mid-autumn (MarchApril and February-March). Sampling date influenced $\mathrm{T}_{4}(\mathrm{p}<0.001)$ but there was no effect of breed or interaction between breed and sampling date. 


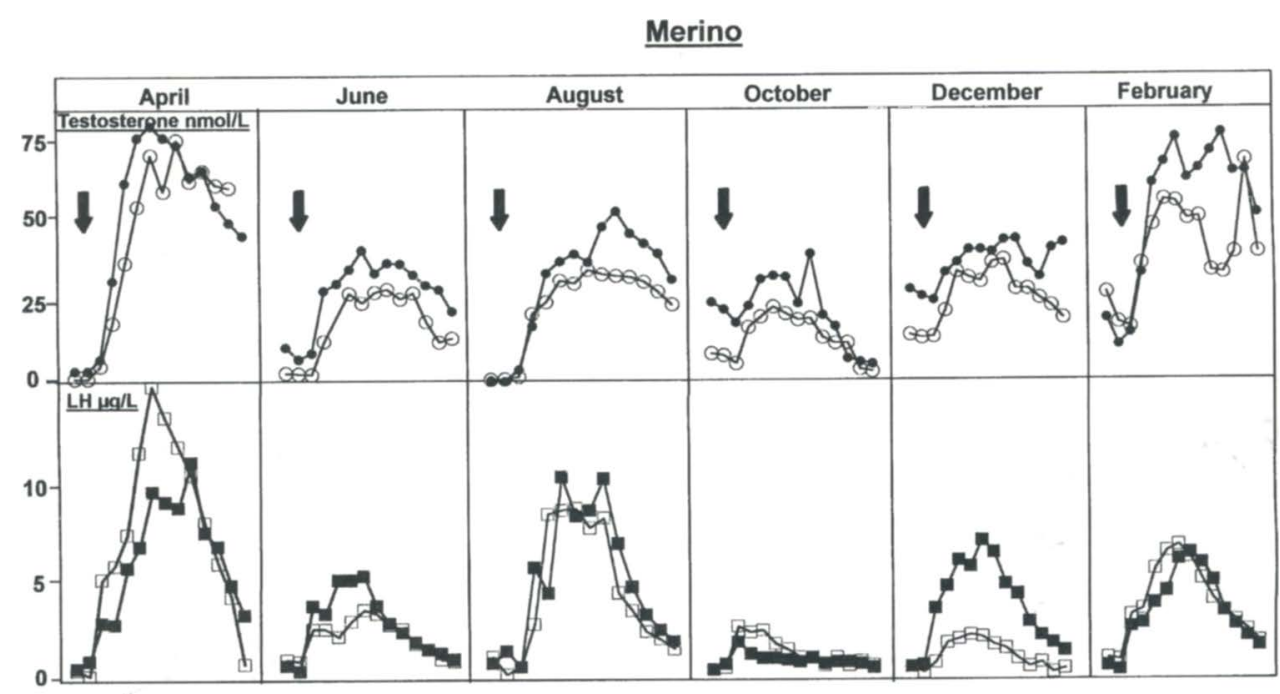

Hormone release 20 min before until $240 \mathrm{~min}$ after $\mathrm{GnRH}$ injection

Figure 4. Plasma concentrations of LH (lower panel) and testosterone (upper panel) in 2 Merino rams after a single intravenous injection of GnRH $(10 \mu \mathrm{g})$ in April, June, August, October, December and February. GnRH was injected immediately after collection of the second blood sample. Animals were grazing on native pasture in a subtropical climate $\left(34^{\circ} \mathrm{S}, 56^{\circ} \mathrm{W}\right)$.

\section{Discussion}

One important finding from the present study was the observed difference between Merino and Corriedale rams in the seasonal changes in LW and SC. The changes in LW and SC was more firmly coupled in Merino rams than in Corriedale - the annual patterns of the 2 parameters were parallel in Merino, while in Corriedale there was a dissociation during autumn and summer. In fact, $68 \%$ of the changes in SC could be explained by changes in LW in Merino, while in Corriedale changes in LW only attributed to $33 \%$ of the change in SC. Since changes in body weight is a reliable indicator reflecting changes in the accumulation and loss of energy one could speculate that nutritional factors may have less influence on the testicular cycle in Corriedale rams than in Merino. Nutrition is a factor influencing the reproductive sea- sonality of Merino rams, since it can override the negative effect of photoperiod (Master \& Fels 1984, Martin et al. 1994a,b). It has also been reported that nutrition affects testicular growth in Merino rams during both the breeding and non-breeding season, while the testes of rams of the strongly photoperiodic Suffolk breed only respond to nutrition when the hypothalamic reproductive centres are not inhibited by photoperiod (Hötzel et al. 1994). The role of nutrition and photoperiod in regulation of seasonal reproduction in Corriedale rams is not well studied. Corriedale rams may, however, be less susceptible to nutrition than the Merino since a better plane of nutrition in late winter increased LW but failed to stimulate an increase in SC (Pérez et al. 1997). In addition, neither nutritional supplementation of Corriedale rams during autumn, which maintained LW (Pérez et 


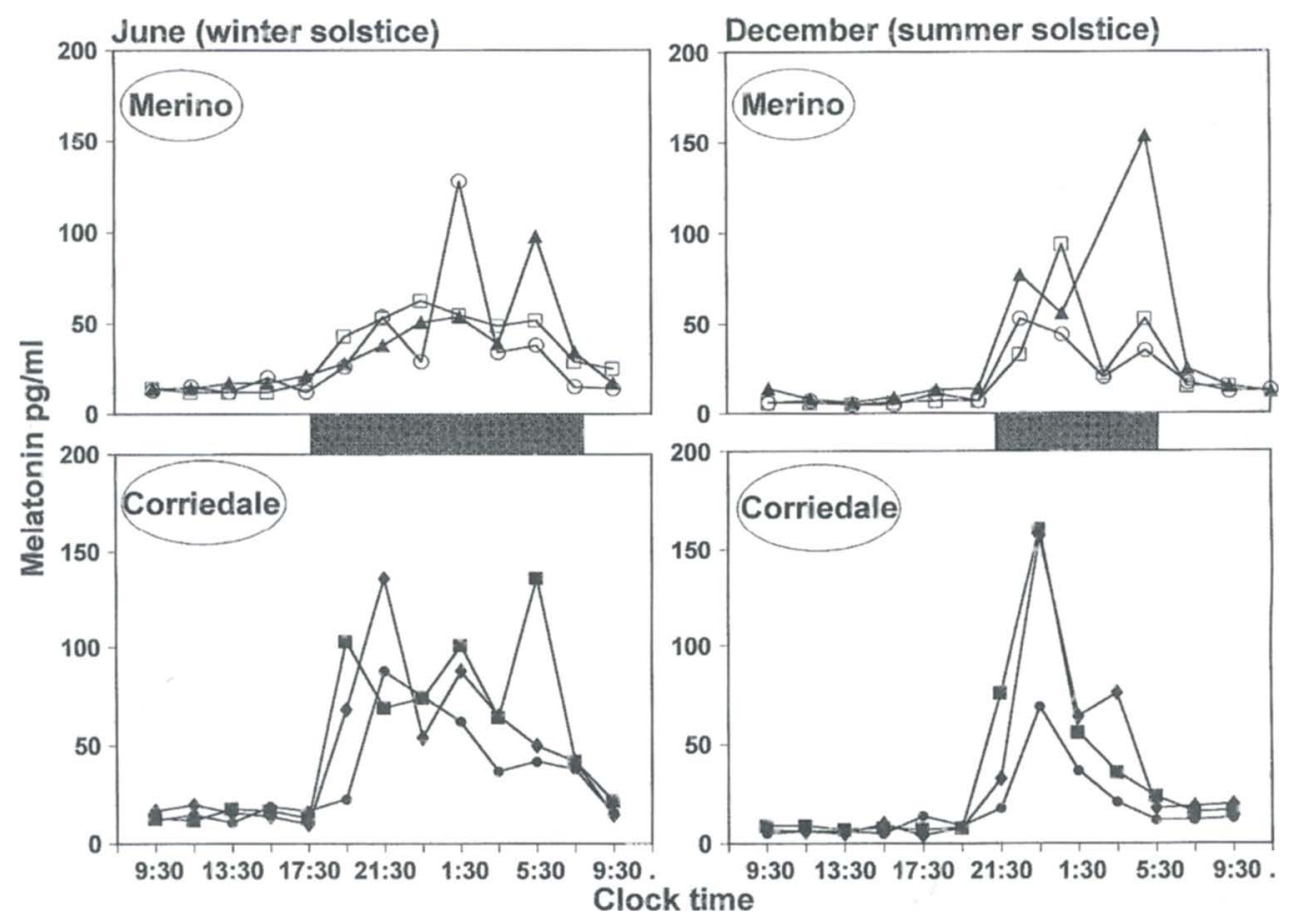

Figure 5. Plasma melatonin concentration during $24 \mathrm{~h}$ periods at the winter (June) and summer (December) solstices in Corriedale $(n=3)$ and Merino $(n=3)$ rams grazing on native pasture in a subtropical climate $\left(34^{\circ} S\right.$, $\left.56^{\circ} \mathrm{W}\right)$. The dark bars indicate the period between sunset and sunrise.

al. 1997) or supplementation during winter, which increased LW could prevent a decrease in SC (Bielli et al. 1996).

The present study showed an interacton between breed and month (sampling date) in T response to GnRH challenge but failed to show any significant effect of breed. This interaction could be an evidence of a difference between Merino and Corriedale testes to respond to $\mathrm{LH}$ at different stages of the annual reproductive cycle. However, the results should be interpreted with caution - they could be due to individual differences since few animals were used and there was no difference in monthly plasma $T$ concentrations between breeds.

There was a strong effect of sampling date on number of LH pulses and pituitary LH response after GnRH administration despite the low number of animals used. The number of LH pulses in Merino as well as Corriedale, on the different sampling occasions, were similar to those found in Préaple de Sud rams by Pelletier et al. (1982) - LH pulsatility increased after the winter solstice, before the start of the breeding season. Both breeds showed similar seasonal pituitary responsiveness to $\mathrm{GnRH}$, and results are in agreement with what was reported for Merino rams subjected to artificial photoperiod (Poulton \& Robinson 1987), and the LH response during spring and autumn was similar to the results obtained by Xu et al. (1991) in Romney and Poll Dorset rams exposed to natural 


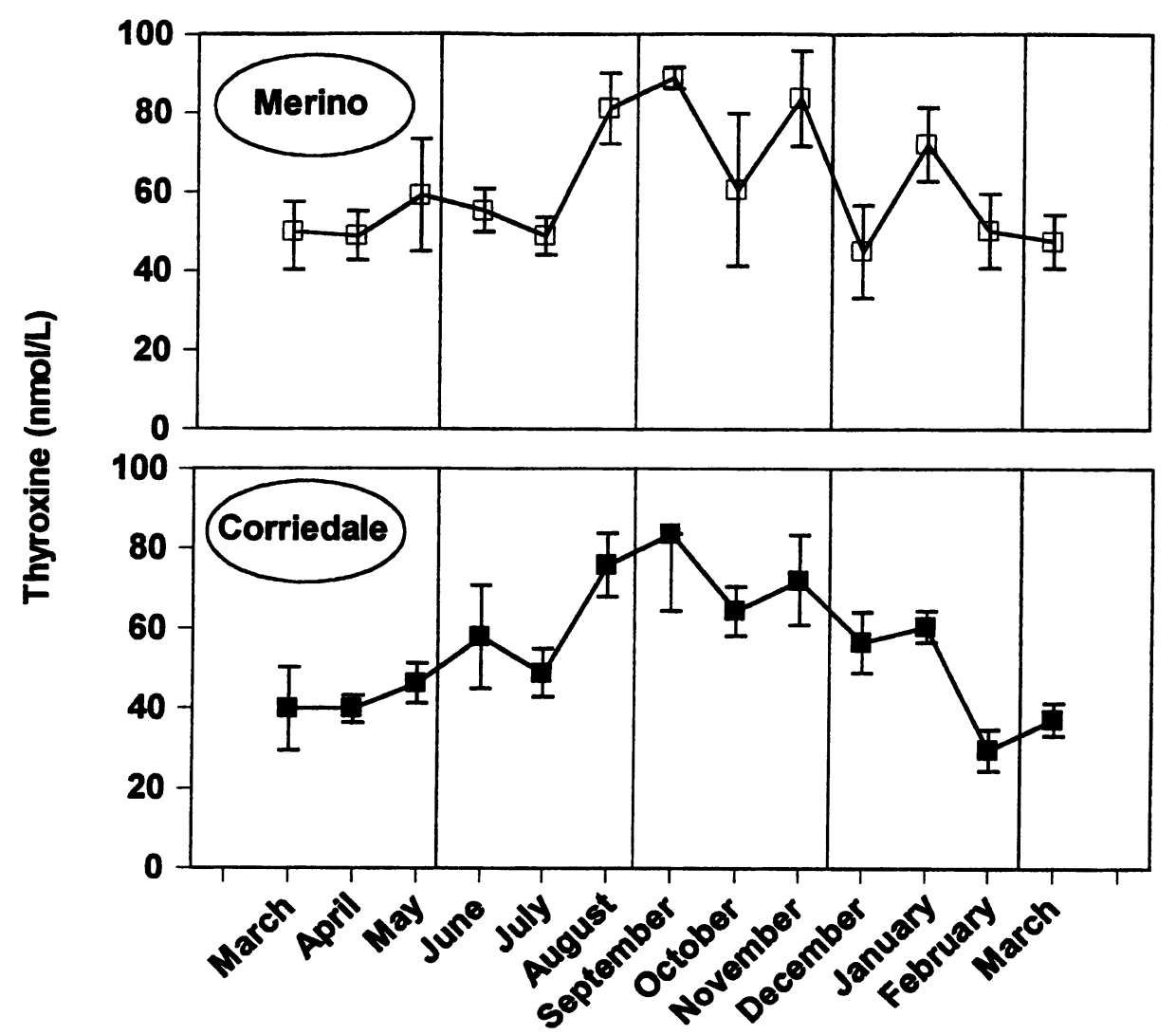

Figure 6. Seasonal variations in plasma concentration in thyroxine in Corriedale (lower panel); $n=9$ ) and Merino (upper panel; $n=6$ ) rams grazing on native pasture in a subtropical climate. Monthly data are based on pools of 3 samples collected 60 min apart.

light. We found low $\mathrm{LH}$ response in winter (June) during short days, when SC, T and number of LH pulses were low (the "system was shut off"). LH response then increased in late winter (August) and decreased again in spring (October) when $\mathrm{T}$ concentrations were increasing. The decrease was more evident in Merino rams. On the other hand, at the end of the breeding season (April) LH response was high in both breeds despite high circulating levels of $\mathrm{T}$. This suggests that the pituitary may have a different sensitivity to the negative feed-back ef- fects of $T$ at different stages of the reproductive cycle. Indeed, indirect evidence for this suggestion can be found in a report by Lincoln (1977), who reported that $\mathrm{T}$ decreased pituitary $\mathrm{LH}$ response to exogenous GnRH during long days but not during short days.

Both breeds expressed similar seasonal rhytms in $\mathrm{T}_{4}$ quite similar to what has been reported earlier in Corriedale (Pérez et al. 1997) and Welsh Mountain rams (Parkinson \& Follet 1994). Maximal concentrations were observed during spring. $\mathrm{T}_{4}$ was very low in late sum- 
mer/autumn (February-April) when SC and concentrations of $\mathrm{T}$ were high. However, this does not imply that there would be a causal relationship between $T_{4}$ and $T$. Other studies show that $\mathrm{T}_{4}$ plays a permissive rather than a regulatory role in male reproductive function (Chandrasekhar et al. 1986, Parkinson et al. 1995, Parkinson \& Follett 1995).

This study could confirm that the $24 \mathrm{~h} \mathrm{M}$ secretion was comparable to what has been reported in other breeds of sheep and in other species (for review see: Arendt et al. 1988). The main features conformed was that (1) $M$ secretion was low during the day and increased markedly during night, (2) Maximum night-time concentrations did not vary markedly between the summer and winter and (3) night-time $M$ secretion varied between summer and winter and was longest during the short day of the winter. In other words, both breeds possess the necessary signal system which should enable them to interpret changes in photoperiod.

We conclude that Corriedale and Merino rams in a subtropical climate have annual reproductive cycles - testes - and pituitary activity change throughout the year. The changes in testes activity is a very constant pattern observed throughout our studies of Corriedale rams (Pérez et al. 1996, Pérez et al. 1997) and from reports of Merino rams (Masters \& Fels 1984, Gibbons et al. 1991, Martin et al. 1994a,b). However, the mechanisms involved in the regulation of the reproductive cycle of the 2 breeds may not be exactly the same. Merino has been described as an "opportunistic breed" (Martin et al. 1994b), which means that the Merino ram can respond to changes in photoperiod at latitudes comparable to this study, but when the availability of food is not in concordance with changes in daylength, food supply has more impact on the testes cycle. On the other hand, in Corriedale rams changes in LW and testes activity are more dissociated under subtropical conditions, which could reflect that the reproductive cycle is more strongly governed by changes in photoperiod.

\section{Acknowledgements}

The authors wish to thank Ing. Agr Andrés Ganzábal, Ana Nicola, Carolina Chiesa, Dr. Alvaro López, Dr. Elize Van Lier and Dr. Mariel Regueiro for technical assistance during the experimental work, Mari-Anne Carlsson and Karin Burvall for the laboratory assistance and Ing. Juan Burgueño for his excellent help with the statistical analyses. We also thank Dr. Steven Walkden-Brown for scientific support. Financial support was recieved from the International Foundation for Science (IFS) (Grant B/1917-1). Dr. Raquel Pérez Clariget is holder of a scholarship from CONICYT of the Uruguayan Government which supports her studies in Sweden.

\section{References}

Arendt J, Symons AM, English J, Poulton L, Tobler I: How does melatonin control seasonal reproductive cycles? Reprod. Nutr. Dévelop. 1988, 28 (2B), 387-397.

Bielli A, Pedrana G, Gastel MT, Moraña JA, Castrillejo A, Piaggio J, Forsberg $M$, RodriguezMartínez $H$ : La suplementación nutricional evita la caida invernal en la reproducción estacional del carnero Corriedale uruguayo? (Nutritional supplement can avoid the winter decreasing of the seasonal reproduction in Uruguyan Corriedale rams?) 2do Simp. Intern. Reprod. Anim., 31 de octubre - 2 de noviembre, Carlos Paz, Córdoba, Argentina. 1996, p. 247.

Castrillejo A, Moraña JA, Bielli A, Gastel T, Molina $J R$, Forsberg M, Rodriguez-Martínez H: Onset of spermatogenesis in Corriedale ram lambs under extensive rearing conditions in Uruguay. Acta vet. scand. 1995, 36, 161-173.

Chandrasekhar MJ, D'Occhio MJ, Setchell BP: Reproductive hormone secretion and spermatogenic function in thyroidectomized rams receiving graded doses of exogenous thyroxine. J. Endocr. 1986, 111, 245-253.

D'Occhio $M J$, Brooks DE: Seasonal changes in plasma testosterone concentration and mating activity in Border Leicester, Poll Dorset, Romney and Suffolk rams. Aust. J. Exp. Agric. Anim. Husb. 1983, 23, 248-253. 
Forsberg M, Tagle R, Madej A, Molina JR, Carlsson $M-A$ : Radioimmunoassay of bovine, ovine and porcine luteinizing hormone with a monoclonal antibody and a human tracer. Acta vet. scand. 1993, 34, 225-262.

Gastel T, Bielli A, Pérez R, López A, Castrillejo A, Tagle $R$, Franco $J$, Laborde $D$, Forsberg $M$, Rodrigues-Martinez $H$ : Seasonal variations in testicular morphology in Uruguyan Corriedale rams. Anim. Reprod. Sci. 1995, 40, 59-75.

Gibbons A, Vinent JG, Willems $P$, González R: Variación estacional de la actividad reproductiva del carnero Merino Australiano en la Patogonia. (Seasonal changes in reproductive activity of Australian Merino in Patagonia). Rev. Arg. Prod. Anim. 1991, 11, 449-455.

Glover TD, D'Occhio MJ, Millar RP: Male life cycle and seasonality. In: Lamming G.E. (Editor), "Marshall's Physiology of Reproduction", Vol. II: Reproduction in the male. 4th Ed., ChurchillLivingstone, London, 1990 pp. 213-378.

Hötzel MJ, Martin GB, Walkden-Brown SW, Fisher $J S$ : Nutritional effects on testicular growth and LH and FSH secretion in Suffolk and Merino rams during the breeding and the non-breeding seasons. Twentysixth Annual Conference of The Australian Society for Reproductive Biology Inc. September 26-28, Brisbane, Australia 1994.

Islam ABMM, Land RB: Seasonal variation in testis diameter and sperm output of rams of breeds of different prolificacy. Anim. Prod. 1977, 25, 311317.

Lincoln GA: Changes in pituitary responsiveness to luteinizing hormone releasing in rams exposed to artificial photoperiods. J. of Endocrinology 1977, 73, 519-527.

Lincoln GA, Lincoln CE, McNeilly AS: Seasonal cycles in the blood plasma concentration of FSH, inhibin and testosterone size in rams of wild, feral and domesticated breeds of sheep. J. Reprod. Fert. 1990, 88, 623-633.

Lincoln GA, Short RV: Seasonal breeding: Nature's contraceptive. Recent. Prog. Horm. Res. 1980, $36,1-52$.

Martin GB, Ford JR, Purvis IW: Environmental and genetic factors affecting reproductive activity in the Merino ram. In: Reproductive Physiology of Merino Sheep-Concepts and Consequences. School of Agriculture (Animal Science). The University of Western Australia, Perth. 1990.

Martin GB, Sutherland SRD, Lindsay DR: Effects of nutritional supplements on testicular size and the secretion of $\mathrm{LH}$ and testosterone in Merino and Booroola rams. Anim. Reprod. Sci., 1987, 12, 267-281.

Martin GB, Tjondronegoro DW, Blackberry MA: Effects of nutrition on testicular size and the concentrations of gonadotrophins, testosterone and inhibin in plasma of mature sheep. J. Reprod. Fert. 1994a, 101, 121-128.

Martin GB, Walkden-Brown SW, Boukhliq R, Tjondronegoro S, Miller DW, Fisher JS, Hötzel MJ, Restall BJ, Adams NR: Non-photoperiodic inputs into seasonal breeding in male ruminants. In Perspective in Comparative Endocrinology, National Research Council of Canada, Ottawa, 1994b, pp. 574-585.

Masters G, Fels HE: Seasonal changes in the testicular size og grazing rams. Anim. Prod. in Aust. 1984, 15, 444-447.

Mickelsen WD, Paisley LG, Dahmen JJ: The effects of season on the scrotal circumference and sperm motility and morphology in rams. Theriogenology, 1981, 16, 45-51.

Parkinson TJ, Douthwaite JA, Follet BK: Responses of prepubertal and mature rams to thyroidectomy. J. Reprod. Fert. 1995, 104, 51-56.

Parkinson TJ, Follet BK: Effect of thyroidectomy upon seasonality in rams. J. Reprod. Fert. 1994, 101, 51-58.

Parkinson TJ, Follet BK: Thyriodectomy abolishes seasonal testicular cycles in Soay rams. Proc. R. Soc. Lond. B. Biol. Sci. 1995, Jan 23, 259 (1354), 1-6.

Pelletier J, Almeida G: Short light cycles induce persistent reproductive activity in Ile-de-France rams. J. Reprod. Fert. Suppl. 1987, 34, 215-226.

Pelletier D, Garnier DH, de Riviers MM, Terqui M, Ortavant $R$ : Seasonal variation in LH and testosterone release in rams of two breeds. J. Reprod. Fert. 1982, 64, 341-436.

Pérez Clariget R, López A, Castrillejo A, Bielli A, Laborde D, Gastel T, Tagle R, Queirolo D, Franco J, Forsberg M, Rodriguez-Martínez H: Reproductive seasonality of Corriedale rams under extensive rearing conditions. Acta vet. scand. 1997, 38, 109-117,

Pérez Clariget R, López A, Castrillejo A, Forsberg $M$ : Effect of season and feeding level on live weight, testes size and testosterone concentration in Uruguyan Corriedale rams. Proc. 13th International Congress on Animal Reproduction, June 30-July 4, Sydney, Australia. 1996, P1-6.

Poulton AL, Robinson TJ: The response of rams and 
ewes of three breeds to artifical photoperiod. J. Reprod. Fert. 1987, 79, 609-626.

Ritar AJ, Adams NR, Sanders MR: Effect of lupin feeding on LH, testosterone and testes. In: Reproduction in Sheep. D. R. Lindsay and D.T. Pearce (eds.), Cambridge University Press. 1984, pp. 76-78.

Rodriguez A: Crecimiento estacional de la en ovinos Merino e Ideal en pastoreo (Wool seasonal growth in Merino and Polwarth sheep under forage conditions). Prod. Ovina, SUL, Paysandú, Uruguay. 1989, 1, 45-50.

Sanford LM, Palmer WM, Howland BE: Influence of sexual activity on serum levels of LH and testosterone in the ram. Canadian J. Anim. Sci. 1974, $54,579-585$.

Xu ZZ, McDonald MF, McCutcheon SN, Blair HT: Seasonal variation in testis size, gonadotrophin secretion and pituitary responsiveness to $\mathrm{GnRH}$ in rams of two breeds differing in time of onset the breeding season. Anim. Reprod. Sci. 1991, 26, 281-292.

Zarco, L, Stabenfeldt GH, Kindahl H, Quirke JF, Granstrom E: Persistence of luteal activity in the non-pregnant ewe. Anim. Reprod. Sci. 1984, 7, 1-3, 245-267.

\section{Sammanfattning}

Säsongsmässig variation i levande vikt, testikelstorlek, testosteron, LH, melatonin och tyroxin hos Merino och Corriedalebaggar under subtropiska förhållanden.

En undersökning genomfördes för att studera de säsongmässiga förändringarna $i$ levande vikt och en- dokrin aktivitet i testiklar och hypofys hos Merino$(n=7)$ och Corriedale- $(n=9)$ baggar under subtropiska förhållanden. Som ett mått på testikelaktiviteten studerades testikelomfång, plasma koncentrationen av testosteron och testosteronutsöndring efter injektion av GnRH. LH pulsatilitet och plasmakoncentration av LH efter injektion av GnRH användes som ett mått på hypofysaktiviteten. Dessutom mättes de säsongsmässiga förändringarna $\mathrm{i}$ tyroxin och dygnsförändringarna i plasmakoncentrationen av melatonin vid vinter- och sommarsolstånden. Den statistiska analysen visade inga rasskillnader mellan Merino och Corriedale vad avser de parametrar som studerades. Det fanns en interaktion mellan ras och provtagningstidpunkt $i$ levande vikt $(p<0.001)$ och testosteronsekretion efter GnRH injektion. Hos båda raserna minskade testikelomfånget under hösten och ökade under våren $(\mathrm{p}<0.05)$. De lägsta testosteronnivåerna uppmättes under sen höst och de högsta under sommar/tidig höst $(p<0.05)$. LH pusatiliteten var lägst under vintern och högst under tidig höst $(\mathrm{p}<0.05)$. Testosteron och LH sekretionen efter GnRH injektion var högst under hösten hos båda raserna $(p<0.05)$. De högsta koncentrationerna av melatonin registrerades under den mörka delen av dygnet hos både Merino och Corriedale både vid vinteroch sommarsolståndet. Tyroxin var högst hos båda raserna vid slutet av vintern/början av våren och lågt under resten av året. Resultaten visat att såväl Merino- som Corriedalebaggar har en säsongsmässig fortplantningscykel under subtropiska förhållanden. Det fanns ett starkare samband mellan förändringarna i levande vikt och testikelomfång $(p<0.001)$ hos Merino $\left(R^{2}=0.68\right)$ än hos Corriedale $\left(R^{2}=0.33\right)$, vilket kan tyda på att nutritionella faktorer kan ha ett större inflytande på fortplantningscykeln hos Merino än Corriedale.

(Received May 7, 1996; accepted October 2, 1997).

Reprints may be obtained from: Raquel Pérez, Dept. of Anim. Anatomy and Physiology, Faculty of Agronomy, University of Uruguay, Montevideo, Uruguay. E-mail: raquelpl@ata.edu.uy, fax: +598 2 393004, tel: + 598-2 341564 . 